activity it seems likely that regression follows interference with the tumour's hormonal environment. A. I. Sherman and R. B. Woolf ${ }^{11}$ have suggested from their study of endometrial cancer that for hormone-dependent tumour to respond to progestogens some priming with small amounts of oestrogen is required, and this view has been supported for breast cancer. ${ }^{612}$

In the male a few reports have noted the value of progestogens in advanced cancer of the breast, ${ }^{13}$ while hydroxyprogesterone caproate ${ }^{14}$ and cyproterone acetate ${ }^{15}$ have been found useful in the palliative treatment of advanced carcinoma of the prostate. In the latter disease patients felt subjective improvement, with relief of pain, and objectively they gained weight, the serum acid phosphatase fell, and the prostate decreased in size.

C. H. Paine and his co-authors ${ }^{16}$ have reported the effect of medroxyprogesterone acetate (Provera) on 25 patients with metastatic tumours of renal, endometrial, and other sites. They found that four out of seven patients with metastatic adenocarcinoma of the corpus uteri responded, but in one patient with vaginal and another with ovarian carcinoma no benefit was noted. Of much greater interest, they found that in 15 patients ( 12 men and three women) with hypernephroma, three men showed objective improvement. Two patients had lung deposits and one a pleural effusion. As noted with breast cancer, those with bone metastases did not respond.

H. J. G. Bloom ${ }^{17} 18$ has drawn attention to the probable existence of a hormonal background to the development and progress of carcinoma of the kidney in man. Of 38 patients on whom he reported all had evidence of multiple metastases, and $34(89 \%)$ had had histological confirmation of the diagnosis. Treatment included medroxyprogesterone, testosterone, oestrogens, and prednisone. Eighteen patients $(47 \%)$ felt better subjectively, and in eight cases $(21 \%)$ the radiological or clinical signs showed improvement. Thus hormone treatment of renal carcinoma in this series gave results of the kind seen in many series of patients with breast cancer receiving oestrogens or androgens. The policy, once the disease is seen to be progressing, is to begin with medroxyprogesterone $100 \mathrm{mg}$ three times daily by mouth. If the patient fails to respond within six to eight weeks a change is made to testosterone proprionate $100 \mathrm{mg}$ daily five times a week. If this fails, prednisone 5 to $10 \mathrm{mg}$ four times daily or stilboestrol 5 to $10 \mathrm{mg}$ three times daily are tried.

Progestogens have a place in the treatment of advanced cancer of the breast but certainly not before oestrogens or androgens have been tried. The case for their use in endometrial carcinoma is stronger, and certainly in advanced metastatic renal carcinoma there can be little doubt that they should be given. Bloom noted only one case in which the patient's condition was aggravated by progestogen-and this in a disease from which only one in five patients survive ten years. ${ }^{19}$ It is to be hoped more trials of hormones in the treatment of renal tumour will be undertaken.

1 Greenblatt, R. B., Medical Science (Philadelphia), 1967, 18, No. 5, p. 37. 2 Briggs, M. H., Caldwell, A. D. S., and Pitchford, A. G., Hospital Medicine,

1967, 2, 63.
3 Huggins, C., fournal of the American Medical Association, 1963, 186, 481 .

4 Jolles, B., and Harrison, R. G., Annual Report of the British Empire Cancer Campaign for Research, 1963, 41, Part 2, p. 654 .

5 Notter, G., and Kaigas, M., Münchener medizinische Wochenschrift, 1966, 108, 1920

6 Jolles, B., British Medical fournal, 1967, 3, 682.

7 Curwen, S., Clinical Radiology, 1963, 14, 445.

Stoll, B. A., Medical fournal of Australia, 1966, 1, 331.

9 Kistner, R. W., in Proceedings of the 5th World Congress of Gynaecology and Obstetrics, ed. C. Wood, p. 663. Sydney, Butterworths, 1967.
10 Peck, J. G., and Boyes, D. A., American Fournal of Obstetrics and

1 Sherman, A. I., and Woolf, R. B., American fournal of Obstetrics and Gynecology, 1959, 77, 233.

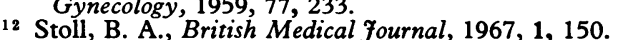

13 Muggia, F. M., British Medical fournal, 1969, 3, 179.

Muggia, F. M., British Medical fournal, 1969, 3, 179. Geller, J., Fruchtman, B., Newman, H., Roberts, T., and Silva, R., Cancer Chemotherapy Reports, 1967, 51, 41.

5 Scott, W. W., and Schirmer, H. K. A., Transactions of the American Association of Genito-Urinary Surgeons, 1966, 58, 54.

16 Paine, C. H., Wright, F. W., and Ellis, F., British fournal of Cancer, 1970, 24, 277.

17 Bloom, H. J. G., in Tumours of the Kidney and Ureter, ed. E. W. Riches, p. 311. London, Livingstone, 1964.

18 Bloom, H. J. G., in Renal Neoplasia, ed. J. S. King. Boston, Little,

19 Riches, E. W., fournal of Urology, 1958, 79, 190.

\section{Bacteriuria Again}

Bacteriuria is still defined by quantitative bacteriological examination of fresh urine. Dip inoculation plates make a good, convenient, semi-quantitative screening test. ${ }^{1}$ Other methods such as the triphenyl tetrazolium chloride (TTC) test $^{2}$ and glucose urinary dip sticks ${ }^{3}$ have proved about $90 \%$ reliable; they also have the advantage of giving a quick result. Surveys which have used these techniques have shown that the incidence of bacteriuria in the general population varies between $0.03 \%$ for schoolboys ${ }^{4}$ and more than $20 \%$ for men and women over 70 years old. ${ }^{5}$ About $5 \%$ of women, whether pregnant or not, have bacteriuria. 6 7

The crucial question is: To what extent does bacteriuria matter? Should all individuals who have it undergo long-term surveillance, let alone treatment? As has been emphasized, ${ }^{1} 9$ bacteriuria is a finding, not a disease. No survey has identified a subgroup of adult patients with bacteriuria who are likely to suffer rapidly deteriorating renal function. Indeed, bacteriuria is so common that it cannot frequently be associated with decline into renal failure. Many surveys have been solely concerned with a bacteriological follow-up and do not report on changes of renal function. Those that do report on them describe, in general, only minor changes. ${ }^{8}$ More data are needed. It is probable that most patients keep their bacteriuria for many years.

Though the mortality appears to be low, the morbidity is high. If they are asked about them, $30-80 \%$ of patients with so-called asymptomatic bacteriuria have specific symptoms. ${ }^{910}$ Children have urgency, enuresis, daytime incontinence, and unexplained fevers. Adults suffer the usual symptoms of "cystitis." Some long-term associations of bacteriuria have been described: 5-year-old girls in Dundee with bacteriuria were shorter than their healthy classmates ${ }^{10}$; adult women with bacteriuria were more frequently hypertensive than those without ${ }^{7} ; 15 \%$ of women with a diastolic pressure about $110 \mathrm{~mm} \mathrm{Hg}$ had infected urine. ${ }^{11}$

Once bacteriuria has been discovered, all patients, both male and female, should ideally have a full radiological investigation of their urinary tract. This is a counsel of perfection, and the numbers involved make it difficult in practice. Such investigation is rewarding, since a large proportion show abnormalities, though many are of doubtful significance. However, about $10 \%$ have renal cortical scars ${ }^{7}$ and $20 \%$ vesicoureteric reflux. ${ }^{610}$ Congenital abnormalities, urethral obstruction, and stones are not uncommon. Most authors report that those patients with radiological abnormalities are the more likely to relapse. This is also true of those with impairment of the renal parenchyma as judged by reduced ability to concentrate the urine or by raised serum antibodies. 
These patients may have fewer symptoms from the relapse ${ }^{12}$ than initially.

This is the group that most clinicians follow up most carefully, though it has been shown that coarse renal scars rarely develop after the age of 6 unless the urinary tract has been altered drastically by analgesic abuse, surgery, or stones. Bilateral renal scars are rarely seen in patients over the age of 35 , and the peak incidence is in the 10-year-olds. ${ }^{13}$ Clinically it is this group of patients, and perhaps they alone, who are in danger of dying from chronic pyelonephritis. If the infection is carefully controlled, the kidneys of these patients will grow. ${ }^{14}$

Otherwise the treatment of bacteriuria has as its principal object the relief of symptoms. In pregnant women it is now well-established that early treatment of symptomless bacteriuria will greatly reduce the incidence of acute pyelonephritis later in pregnancy. ${ }^{15}$ The same is true for non-pregnant women, but their symptoms are less severe. Recurrences are frequent, ${ }^{17}$ usually within two years. ${ }^{9}$ The first treatment offered should be a seven-day course of a sulphonamide, which usually has a success rate of about $90 \%$. Other agents are as effective but are more expensive and less well tolerated. Longer courses of treatment have no advantage at this stage, ${ }^{16}$ and they may obscure the natural history of recurrence in patients with abnormal urinary tracts.

At page 377 of the B.M.F. this week, Dr. W. R. Cattell and his colleagues discuss the management of 52 patients referred to a specialist centre with persistent or recurrent bacteriuria. Forty-eight of them had radiological abnormalities of the urinary tract, in many cases gross. For initial treatment they used a two-week course of an antibiotic followed immediately by a trimethoprim-sulphonamide combination, which was continued for periods of six to 49 months. The amount of these drugs given was reduced until as little as two tablets per week were being taken (this is important in view of the cost of the drugs). They achieved remarkable success in clearing bacteriuria. Six patients had drug intolerance and treatment failed in ten. In the remaining 36 patients only two recurrences occurred while on decreasing therapy. Treatment was stopped in 17 cases, and 10 of them had recurrences, all with the same organism. The other seven remained clear, but none had been followed up for more than 24 months.

These results, in a group of patients notoriously difficult to treat, are encouraging and establish a place for trimethoprimsulphonamide in the management of patients with recurrent urinary-tract infections and abnormal urinary tracts. The problem of using this combination in patients with severely impaired renal function is still under investigation. Since the two drugs are eliminated by separate mechanisms, ${ }^{18}$ the usual ratio of the drugs may have to be altered in an attempt to obtain the optimal ratio in the urine of this type of patient.

Two groups of patients are still extremely difficult to treat successfully. One comprises patients with calculi which cannot be removed for whatever reason. Cattell and his colleagues failed to control infection in five out of nine such patients and a further patient relapsed following withdrawal of the drug. Rotating chemotherapy has been advocated for this group but is expensive, requires a co-operative patient, and carries the maximum risk of drug sensitization. Frequently the urine cannot be acidified, especially when phosphatic calculi are present and mandelamine cannot be used.

The second difficult group is patients, suffering recurrent infections from Pseudomonas aeruginosa. Cattell and his colleagues treated six such patients, with initial failure or recurrence in all. Frequently these patients have grossly abnormal urinary tracts and some degree of renal insufficiency. They have often been treated with every available drug. Carbenicillin and gentamicin are the two most effective antibiotics. Carbenicillin is required in such large doses that it has to be given intravenously. Gentamicin is notoriously toxic to the eighth nerve and can cause vestibular damage, even when serum levels are within what is considered to be the safe range. It also has to be given parenterally, like colomycin, which is nephrotoxic. With these reservations the trimethoprimsulphonamide combination appears to be a good long-term suppressive or prophylactic for recurrent infections in abnormal urinary tracts.

1 Arneil, G. C., McAllister, T. A., and Kay, P., Lancet, 1970, 1, 119.

2 Simmons, N. A., and Williams, J. D., Lancet, 1962, 1, 1377.

Scherstén, B., Dahlqvist, A., Fritz, H., Köhler, I., and Westlund, I., Fournal of the American Medical Association, 1968, 204, 205.

Kunin, C. N., and Paquin, A. J., in Progress in Pyelonephritis, ed. E. H. Kass, p. 33. Philadelphia, Davis, 1965.

${ }^{3}$ Dontas, A. S., et al., Lancet, 1966, 2, 305.

6 Williams, G. L., Davies, D. K. L., Evans, K. T., and Williams, J. E., Lancet, 1968, 2, 1202.

Sussman, M., et al., British Medical fournal, 1969, 1, 799.

Kass, E. H., Proceedings of the Fourth International Congress of Nephrology, Stockholm, 1969, 3, 360 .

9 Kunin, C. M., New England fournal of Medicine, 1970, 282, 1443

io Sunage, D. C., L., Wilson, M. I., Ross, E. M., and Fee, W. M., British Medical fournal, 1969, 3, 75 .

1 Miall, W. E., Kass, E. H., Ling, J., and Stuart, K. L., British Medical fournal, 1962, 2, 497.

12 Turck, M., Ronald, A. R., and Petersdorf, R. G., New England fournal of Medicine, 1968, 278, 422 .

13 Hodson, C. J., and Wilson, S., British Medical fournal, 1965, 2, 191.

14 Smellie, J. M., and Normand, I. C. S., in Urinary Tract Infection, ed. F. O'Grady and W. Brumfitt, p. 123. London, Oxford University Press, 1968.

15 British Medical fournal, 1970, 4, 631.

16 Brumfitt, W. Proceedings of the Fourth International Congress of Nephrology, Stockholm, 1969, 3, 347 .

17 Asscher, A. W., et al., British Medical fournal, 1969, 1, 804.

18 Sharpstone, P., unpublished data.

19 Wing, A. J., British Medical fournal, 1970, 3, 753.

\section{Annual Meeting at Leicester}

This year the B.M.A. will hold its annual meeting in Leicester towards the end of July. As well as being an interesting city with many historic associations, Leicester has the virtue of being easily accessible by road, rail, and-for visitors who want to take things more calmly-canal. A glance at the provisional programme, published this week in the Supplement, shows that the health and diseases of women will be the theme for discussion at the beginning of the meeting after the opening address from the President-Elect, Sir John Peel. Among the many other subjects the experts will later discuss are malaria and leprosy, symptomatic of the growing importance of tropical diseases being brought into temperate countries as a result of increased travel.

The programme includes information on hotels and other accommodation. Intending visitors are advised to book early. 